\title{
MODERNIDADE, UTOPIA E EUGENIA EM 0 PRESIDENTE NEGRO DE MONTEIRO LOBATO
}

Evanir Pavloski

\begin{abstract}
RESUMO: O presente artigo tem como objetivo discutir as diferentes figurações utópicas apreensíveis no único romance do autor brasileiro Monteiro Lobato, intitulado O presidente negro e publicado em 1926. Após uma breve exposição da associação do autor com alguns dos debates socioculturais que marcaram o início do século $X X$, analisaremos as formas pelas quais o romance evidencia as idealizações e as intolerâncias que permearam esse período, o que demonstra o caráter complexo e, muitas vezes, contraditório não apenas da modernidade, mas também do utopismo como posicionamento crítico diante da realidade. Com isso, pretendemos afirmar a importância da obra que, mesmo tendo completado recentemente noventa anos de sua publicação, ainda problematiza de maneira relevante os tênues limites entre os idílios e os pesadelos sociais.
\end{abstract}

Palavras-chave: Modernidade. Utopia. Eugenia. Lobato.

\section{UM AUTOR ENTRE A TRADIÇÃO E O PROGRESSO}

A intenção de mapear, mesmo que de forma resumida, a produção literária de José Bento Renato Monteiro Lobato não é simples e demanda um trabalho analítico que, definitivamente, extrapolaria as balizas deste artigo. Não obstante, parece-nos relevante estender alguns comentários sobre aspectos retóricos e argumentativos do autor que, no horizonte do pensamento utópico, podem ser percebidos em diferentes obras, especialmente, naquela que nos propomos a discutir em particular.

Em primeiro lugar, o vinculo de Lobato com o chamado Pré-modernismo deve ser considerado não apenas em sua dimensão estética, mas também em sua esfera ideológica, o que revela seu comprometimento com um ideal específico de produção literária. Para o autor, a ficção não pode ser separada dos julgamentos morais de seu realizador. Com isso, a noção de objetividade plena do discurso literário é desmitificada pelo esforço do escritor em conhecer e entender a si mesmo na realidade que o seu texto mimetiza. 
Toda literatura, todo romance, todo poema, por mais impessoal que procure ser, não passa de um julgamento. A ideia moral, que domina mesmo o autor mais liberto de tudo, não permite a simples pintura objetiva. E essa pintura seria um susto e um assombro para o homem, que não consegue jamais conhecer-se a si mesmo porque ninguém o desnuda. (LOBATO, 1959, p. 341).

Essa aparente valorização do aspecto retórico do texto literário nos motiva a ponderar sobre as reflexões que Lobato desenvolve em suas narrativas e como elas tangenciam o pensamento utópico, especialmente no romance O presidente negro ${ }^{1}$ de 1926 . Em Literatura e sociedade (2006), Antonio Candido afirma que o artista brasileiro, em sua busca por autoafirmação, tenta compor uma síntese entre a expressão do local e a utilização de moldes herdados da tradição literária europeia. Candido aponta o Romantismo e o Modernismo como os períodos mais representativos da formação identitária da literatura brasileira e caracteriza, consequentemente, o Pré-Modernismo como um momento de transição entre essas correntes e não necessariamente de ruptura entre uma e outra.

É justamente a participação de Monteiro Lobato neste jogo dialético entre o localismo dos temas e a estrangeirização das formas que pode, em um primeiro momento, lançar luz sobre suas perspectivas éticas e suas concepções artísticas. Lobato almejava a formação de uma dicção literária caracteristicamente brasileira que assumisse as questões nacionais como sua matéria. É justamente esse comprometimento que o fez elogiar as obras de Machado de Assis, Euclides da Cunha e Lima Barreto, nas quais percebia o mesmo esforço de apreensão dos temas locais.

No entanto, Lobato fez parte, como vimos, de uma geração marcada pela transição entre perspectivas estéticas e pela desestabilização da tradição na modernidade, o que fez com que seu projeto literário não fosse isento de contradições e radicalismos.

Primeiramente, é preciso recuperar a visão crítica lobateana sobre estéticas literárias anteriores. O autor satirizava o imaginário romântico ao mesmo tempo em que valorizava a problematização social de realistas europeus como Balzac e Maupassant. Todavia, seu posicionamento diante das duas escolas não foi homogêneo. No que se refere ao Romantismo, por exemplo, as análises de Lobato variaram da cáustica ironia ao reconhecimento de um valor moral, a seu ver, ausente nas obras modernistas. Por um lado, ele admitiu que seu projeto literário de valorização nacional deveria figurar um Brasil que não se identificasse mais com o espaço paradisíaco dos românticos e habitado pelo bom selvagem. "José de Alencar, com um viveiro de araras e graúnas e índios e até uma 'virgem morena de lábios de mel', que temos de

\footnotetext{
${ }^{1} \mathrm{O}$ romance foi publicado na forma de folhetim entre setembro e outubro de 1926. Originalmente, a obra foi apresentada ao público com o título $O$ choque das raças, mas a edição integral lançada pela Companhia Editora Nacional no mesmo ano já trazia o título definitivo.
} 
traduzir para 'índia cor de cuia, com o beiço humido de saliva'” (LOBATO, 1948, p. 47). Mas, por outro lado, ele recuperou a idealização indianista ao estilo do próprio José de Alencar para inscrever no cenário brasileiro a desoladora figura do caboclo. O ensaio "Urupês" traz a seguinte comparação:

Morreu Peri, incomparável idealização dum homem natural como o sonhava Rousseau, protótipo de tantas perfeições humanas, que no romance, ombro a ombro com altos tipos civilizados, a todos sobreleva em beleza d'alma e corpo. Contrapôs-lhe a cruel etnologia dos sertanistas modernos um selvagem real, feio e brutesco, anguloso e desinteressante, tão incapaz, muscularmente, de arrancar uma palmeira, como incapaz, moralmente, de amar Ceci. (LOBATO, 1994, p. 165).

Esse paralelo não nos parece configurar uma revisão de suas críticas ao idealismo nativista romântico, mas um recurso de contraste para discutir o cenário de um meio rural retrógrado e empobrecido, no qual a icônica personagem Jeca Tatu ganhou destaque. Apesar da rejeição ao locus idílico devaneado por autores europeus e brasileiros do século XIX, Lobato valoriza de forma explícita a paisagem natural do nosso país, como podemos notar na passagem a seguir:

No meio da natureza brasílica, tão rica de formas e cores, onde os ipês floridos derramam feitiços no ambiente e a infolhescência dos cedros, às primeiras chuvas de setembro, abre a dança dos tangarás; onde há abelhas de sol, esmeraldas vivas, cigarras, sabiás, luz, cor, perfume, vida dionisíaca em escachôo permanente, o caboclo é o sombrio urupê de pau podre a modorrar silencioso no recesso das grotas. Só ele não fala, não canta, não ri, não ama. Só ele, no meio de tanta vida, não vive... (LOBATO, 1994, p. 176).

Novamente, é perceptível um efeito de contraste na passagem, que se estabelece entre o ambiente natural exuberante e a imagem melancólica do caboclo. O subdesenvolvimento do Jeca Tatu rompe com a figuração do nativo brioso e potencializa a crítica social que o escritor apreciava na literatura realista. Nesse sentido, a descrição do caboclo é uma representação caricatural da estagnação nacional corporificada pelo homem do campo. No entanto, Lobato não subscrevia a perspectiva determinista dos naturalistas, uma vez que, para ele, o desenvolvimento econômico inequivocamente resultaria no aperfeiçoamento social e humano da nação. Em síntese, o progresso técnico e econômico seria a condição para resgatar o caboclo da aparente penúria e para inseri-lo em um processo civilizatório. Devido a esse ufanismo progressista, Lobato se notabilizou como um crítico da estrutura conservadora e aristocrática do Brasil que, segundo ele, dificultava o avanço da nação. Tal posicionamento pode ser apreendido em contos como, por exemplo, "Velha praga” (1914), "Cidades mortas" (1919) e "Café! Café!" (1919). 
Tendo em vista esses apontamentos, salientamos o diálogo que o escritor de Taubaté estabelece com diferentes correntes do pensamento utópico recorrentemente tematizadas pela arte literária. Não pretendemos com isso identificar forçosamente o autor como um utopista tradicional que teria reproduzido o arquétipo narrativo de Thomas More na literatura brasileira. Indubitavelmente, a diversidade temática e estrutural da obra de Lobato inviabiliza um enquadramento dessa ordem. Mas, consideramos importante para nosso estudo perceber que Lobato participou intelectualmente de discussões sociais que, inscritas no turbilhão de transformações da modernidade, tangenciaram recorrentemente os limites do utopismo. Como veremos posteriormente, esse diálogo já se efetivava vários anos antes da publicação de $O$ presidente negro.

É pacífico afirmar que o movimento romântico foi um solo fértil para a gênese de utopias, sendo a mistificação da Natureza e a valorização do bom selvagem aspectos que merecem aqui especial relevo. Tributárias, em grande medida, das reflexões de Jean-Jacques Rousseau, essas idealizações influenciaram também a literatura indianista brasileira do século XIX. Assim, ao recusar essas proposições, Lobato não se opôs apenas a uma visão utópica da natureza humana, mas também a uma diç̧ão literária que a engendrasse. Quando o autor se refere a essa estética como, por exemplo, nos trechos de cartas que citamos anteriormente, ele o faz como mecanismo contrastivo para debater a situação nacional. Assim, o utopismo dos românticos pode ser entendido como antiutópico no projeto nacionalista do escritor brasileiro, ou seja, o idílio romântico é divergente das concepções sociais e literárias de Lobato.

Em contrapartida, o entendimento da arte literária como representação de uma realidade social que precisa ser discutida e transformada não se afasta totalmente de uma visão utópica sobre o potencial simbólico da literatura. Nesse sentido, o viés sociológico de Lobato configura uma proposta retórica de desvelamento das desigualdades econômicas e culturais do Brasil, que poderia, inclusive, provocar transformações empíricas. Essa perspectiva transformadora é também um dos pressupostos da literatura utópica, ou seja, oferecer por meio da ficção um parâmetro de comparação e crítica do universo experimental.

Afirma-se que, a menos que possamos conceber algo perfeito, não podemos entender o que significa a imperfeição. Se, digamos, nos queixarmos de nossa condição aqui na terra apontando para o conflito, a miséria, a crueldade, o vício - "as desgraças, loucuras e crimes da humanidade" - se, em suma, afirmarmos quer nosso estado está longe da perfeição, isso só se torna inteligível pela comparação com um mundo mais perfeito; é pela avaliação do hiato entre os dois que podemos avaliar a extensão daquilo que falta a nosso mundo. E o que lhe falta? A idéia daquilo que falta é a idéia de um estado de perfeição. Acredito que seja isto o que subjaz ao pensamento utópico e, na verdade, a grande parte do pensamento ocidental 
como um todo; de fato, parece estar no centro desse pensamento, de Pitágoras e Platão em diante. (BERLIN, 1991, p. 33-34).

Esse utopismo nacionalista de Lobato pode ser associado tanto a algumas vertentes do Realismo oitocentista quanto ao esforço de ruptura e de investigação do panorama social brasileiro presente no Modernismo.

Em seu artigo "Brasil: nações imaginadas", José Murilo de Carvalho analisa as concepções de nação e nacionalismo em diferentes épocas da nossa história e aponta o caráter idealístico de seus usos. Com a Proclamação da República, a busca pela identidade nacional se tornava mais iminente e oportunizava uma visão utópica do desenvolvimento do país.

\begin{abstract}
A República foi proclamada, sem participação popular. Mas os conflitos que se seguiram à sua proclamação e à necessidade de afirmar-se como nova forma de governo em oposição à monarquia contribuíram para renovar o debate em torno do problema nacional. Eliminada a dinastia portuguesa, o País ficava entregue a si mesmo, e a pergunta sobre o que era esse País tornava-se mais premente. (CARVALHO, 1998, p. 249).
\end{abstract}

Assim, autores como Olavo Bilac, Euclides da Cunha e o próprio Monteiro Lobato acolheram a tarefa de delinear essa identidade nacional e de defender a construção utópica de um novo Brasil. Dentre os discursos defendidos por esse grupo de pensadores, destaca-se uma evidente defesa do "embranquecimento" da população, uma vez que a mestiçagem era tida como uma das causas possíveis para o atraso do país e do problemático reconhecimento dos indivíduos como integrantes do mesmo corpo social.

As posições variavam da hesitação em relação à mestiçagem à total negação da população negra e mestiça. No primeiro caso estão pensadores importantes como Silvio Romero e Euclides da Cunha. Romero de início aceitava a mestiçagem, posteriormente, passou a defender as posições de Gobineau. Euclides julgava severamente os mestiços do litoral, a quem considerava raquíticos e neurastênicos. Mas via na população sertaneja do interior a possível matriz de uma raça saudável. Mais tarde, na segunda década do século, Oliveira Viana retomou de maneira mais elaborada a ideia da inferioridade da raça negra. Em geral, esses autores admitiam a possibilidade de melhoramentos da população mediante seu progressivo branqueamento. (CARVALHO, 1998, p. 251).

Tratando-se de um estudo sobre a obra de Monteiro Lobato, é importante reconhecer que esses esforços em contribuir, por meio da ficção, para a formação de uma identidade nacional se estenderam também para literatura infantil. O caráter formativo do texto literário novamente se manifesta nessa iniciativa, denotando uma visão idealística de seu potencial 
emancipatório. "Essa literatura revela a presença de uma preocupação em definir a identidade da nação e em desenvolver entre a população infantil o sentimento do patriotismo" (CARVALHO, 1998, p. 254). Sem dúvida, as diversas obras de Lobato ambientadas no idílico e tipicamente brasileiro Sítio do Pica-pau Amarelo exemplificam essa tendência.

No entanto, o elemento utópico mais aparente no projeto nacionalista do autor é inequivocamente o ideal de progresso. Desde o período renascentista, quando se reconhece o papel dos indivíduos como potenciais agentes transformadores da realidade, a noção de um processo viável para o aperfeiçoamento das sociedades se torna palpável. Tal compreensão não apenas desafiou a escolástica cristã e sua interpretação autocrática do real, mas também motivou a produção de diferentes utopias progressistas em maior ou menor grau. Recorrentemente, a valorização da ciência como instrumento para a evolução das comunidades foi perceptível em figurações utópicas como, por exemplo, A nova Atlântida (1624) de Francis Bacon. Esse ufanismo cientificista sedimentou o caminho para os positivistas do século XIX como Augusto Comte e Herbert Spencer, pensadores frequentemente citados por Lobato em suas correspondências com Godofredo Rangel. Considerando essa expansão das teorias de transformação social, Jacob Guinsburg (2005) afirma que os Oitocentos foi o período no qual a idealização do progresso alcança o status de axioma.

Com efeito, a noção de progresso começa a instalar-se agora na arena historiosófica, como um dos principais sucedâneos do arbítrio divino e, mesmo, deste como ato pessoal de Deus, da finalidade providencial, tanto mais quanto encerra, senão um paraíso como termo, pelo menos um "mundo sempre melhor" como uma proximidade terrena, dentro do tempo histórico, dependente apenas da atuação do homem. (GUINSBURG, 2005, p. 14-15).

Em território brasileiro, Monteiro Lobato defendeu o desenvolvimento científico, econômico e cultural como forma de libertar o país da influência europeia e de consolidar a tão almejada identidade nacional. Dentre os seus vários argumentos, Lobato enfatizou a exploração do ferro e do petróleo como projeto viável de fortalecimento da coesão e da soberania de um Brasil, naquele momento, ainda utópico.

O meio inteligente de sustar o separatismo e o comunismo é indireto: é dando ferro e petróleo ao país. Ferro, matéria prima da maquina; petróleo, matéria prima da energia que move a maquina. Com a máquina teremos transporte e, portanto, mobilização das riquezas nacionais. Essa mobilização trará onimoda riqueza, trará destruição dos regionalismos hostis, trará alivio á miséria do povo, causa de todos os comunismos desesperados. (LOBATO, 1948, p. 255). 
Essa arraigada defesa do progresso fez com que o autor reavaliasse a caracterização do Jeca Tatu como símbolo de decadência da nação. Afastando-se de uma perspectiva determinista, o autor defende que o caboclo pode superar sua condição problemática desde que seja beneficiado por transformações econômicas e culturais que incidam sobre toda a esfera social. Dessa forma, Lobato refutou a ideia de que o Brasil está destinado ao fracasso ao associar o ideal de progresso à construção de um futuro melhor.

O nacionalismo aparente do autor não o impediu, no entanto, de eleger uma estrutura social que, segundo o seu ponto de vista, deveria servir de modelo para o desenvolvimento brasileiro: os Estados Unidos. Em diversas cartas, Lobato exprimiu a sua admiração pelas instituições democráticas, pelos avanços técnico-científicos e pela independência cultural do país em relação aos moldes do chamado velho mundo. O escritor identificou a eficiência do indivíduo estadunidense como elemento fundamental para a prosperidade daquele país, que, em sua caracterização utópica, servia de parâmetro de contraste à realidade brasileira.

O problema focalizara-se em meu espírito sob uma forma simplista: Por que, dos dois maiores países da América, descobertos no mesmo ciclo, povoados com os mesmos elementos (europeu, índio e negro), libertados politicamente quasi na mesma época, com territórios equivalentes, um se tornou o mais rico e poderoso do mundo e o outro permanece encruado? A atenta observação do fenômeno americano deu-me a resposta clara: Porque nos Estados Unidos o homem adquiriu elevada eficiência e no Brasil a eficiência do homem está pouco acima da do homem natural. (LOBATO, 1948, p. 59).

José Murilo de Carvalho afirma que a idealização da sociedade estadunidense foi um recurso constante de pensadores brasileiros para criticar a influência europeia que ainda podia ser percebida no Brasil, o que possibilitou a mitificação de uma ordem social cujo prestígio atravessou o século XX. "[Os Estados Unidos] eram a imagem da liberdade, da iniciativa, da riqueza, do progresso técnico; enfim, do novo mundo americano em oposição ao velho mundo decadente europeu" (CARVALHO, 1998, p. 250).

Não causa estranheza, portanto, que o espaço utópico figurado em 0 presidente negro foi justamente os Estados Unidos do ano 2228, período no qual, devido ao progresso contínuo, a eficiência e a eugenia alcançaram seu ápice. Contudo, essa não é a única faceta do utopismo no romance de Lobato. Analisar outras particularidades dessa obra passa a ser o nosso intuito a partir de agora.

\section{AS UTOPIAS DE UM NOVO SÉCULO}

Já no início do romance, o protagonista Ayrton Lobo é apresentado ao leitor como um homem comum que, inserido em um contexto típico das cidades de grande porte da década de 20 , é diretamente influenciado pelas 
condições sociais da época em que vive. Se, por um lado, uma rotina proletária desgastante lhe é imposta; por outro lado, a perspectiva de usufruto dos bens compensatórios do capitalismo preenche seu horizonte. Nesse sentido, nada mais emblemático que a primeira cena da narrativa ocorra justamente na sala de espera de um banco, instituição ao mesmo tempo responsável pela realização e pela destruição de sonhos modernos. Cabe ainda ressaltar que o diálogo entre Ayrton e um conhecido seu ocorre em uma agência do London Bank, uma alusão irônica da dependência econômica do Brasil de capitais estrangeiros. Neste ambiente, as duas personagens demonstram um aparente desagravo e resignação com a condição das relações humanas orientadas pelo capital. "A vida é complicada, existem leis, polícia, embaraços de toda espécie, burocracia e mil peias, tudo porque a desonestidade nas relações humanas constitui, como dizes, um elemento constante. Mas é mal sem remédio..." (LOBATO, 1979, p. 07).

Contudo, o sujeito com quem Ayrton preenche o tempo de espera sugere uma solução utópica para os problemas gerados pela corrupção humana. Ainda incipiente neste ponto da obra, a referência à eugenia serve como antecipação de um dos temas mais importantes do romance.

\begin{abstract}
Sim, porque se não fosse a desonestidade dos homens tudo se simplificaria grandemente. Esta demora no pagamento do mais simples cheque, donde provém? Da necessidade de controle em vista dos artifícios da desonestidade Fossem todos os homens sérios, não houvesse hipótese de falsificações ou abusos, e o recebimento de um dinheiro far-se-ia instantâneo. Ponho-me ás vezes a imaginar como seriam as coisas cá na terra se um sábio eugenismo desse combate á desonestidade por meio da completa eliminação dos desonestos. Que paraíso! (LOBATO, 1979, p. 07)
\end{abstract}

O trecho acima apresenta dois elementos que merecem destaque. Primeiramente, a menção ao termo paraíso enfatiza o entendimento da eugenia como um mecanismo viável para a formação de uma sociedade modelar, o que será reafirmado posteriormente pelas palestras da personagem Miss Jane. Além disso, é recorrente nas obras da literatura utópica a presença de um preâmbulo que antecede a descrição do idílio social. Nesta espécie de introdução ao cenário utópico, apresenta-se um espaço ficcional que pelo efeito mimético pode ser reconhecido pelo leitor e, ao mesmo tempo, criticado pelas personagens. São os lugares de onde partem os viajantes como Lemuel Gulliver em As viagens de Gulliver (1726) ou para onde retornam os exploradores como Rafael Hitlodeu em A utopia (1516). Em ambos os casos, essa apresentação da realidade social potencializa o contraste a ser efetivado pela descrição da utopia.

A personagem Ayrton Lobo vive diariamente as exigências e as recompensas desse meio social que, já no início do século $X X$, valorizava mais a produtividade material do que a capacidade intelectual. 
Era eu um pobre diabo para toda gente, exceto para mim mesmo. Para mim tinha-me na conta de centro do universo. Penso e sou, dizia comigo, repetindo certo filosofo francês. Tudo gira em redor do meu ser. No dia em que eu deixar de pensar, o mundo acabase. Mas isto parece que não tinha grande originalidade, pois todos os meus conhecidos se julgavam da mesma forma. Eu vivia do meu trabalho, recebendo dele, não o produto, mas uma pequena quota, o necessário para pagar o quarto onde morava, a pensão onde comia e a roupa que vestia. Quem propriamente se gozava do meu trabalho era a dupla Sá, Pato \& Cia., gordos e sólidos negociantes que me enterneciam a alma nas épocas de balanço ao concederem-me a pequena gratificação constituidora do meu lucro. (LOBATO, 1979, p. 08)

Os modestos rendimentos do protagonista permitem que ele participe, de forma também modesta, da mobilidade social que todo sistema apoiado em um suposto ideal meritocrático prevê. Com anos de trabalho e economia, Ayrton adquire um carro que, de acordo com a sua visão, o coloca em uma estirpe notória de indivíduos.

Meu serviço na casa era todo de rua, recebimentos, pagamentos, comissões de toda espécie. De modo que posso dizer que morava na rua, e o mundo para mim não passava de uma rua a dar uma porção de voltas em torno da terra. Ora, na rua eu via a humanidade dividida em duas castas, pedestres e rodantes, como os batizei aos homens comuns e aos que circulavam sobre quatro pneus. O pedestre, casta em que nasci e em que vivi até aos 26 anos, era um ser inquieto, de pouco rendimento, forçado a gastar a sola das botinas, a suar em bicas nos dias quentes, a molhar-se nos dias de chuva e a operar prodígios para não ser amarrotado pelo orgulhoso e impassível rodante, o homem superior que não anda, mas desliza veloz. Quantas vezes não parei nas calçadas para gozar o espetáculo do formigamento dos meus irmãos pedestres, a abrirem alas inquietas á Cadillac arrogante que por eles se metia, a reluzir esmaltes e metais! $O$ ronco de porco do klaxon parecia-me dizer - "Arreda canalha!" (LOBATO, 1979, p. 08)

É interessante notar que o discurso da personagem subscreve uma noção de que a posse de determinados bens materiais não apenas denota valores socialmente reconhecidos como sucesso ou poder, mas também inscreve os indivíduos em grupos humanos distintos ou, como o protagonista os define, castas que dividem a humanidade. Percebe-se, dessa forma, que a valorização de um sistema no qual a ação individual seria efetivamente recompensada pela prosperidade é caracteristicamente utópica. Dentre as raízes possíveis para essa perspectiva, salientamos o saint-simonismo como aquela que parece assumir maior conotação idealística. $\mathrm{O}$ aristocrata e economista francês Claude-Henry de Rouvroy, o Conde de Saint-Simon, participou ativamente da Revolução Americana e defendeu um positivismo 
progressista que teve, dentre seus interlocutores, o seu secretário particular Augusto Comte.

No pensamento saint-simoniano encontramos a afirmação de que a organização econômica é primordial e mais relevante do que a preocupação político-institucional, pondo mesmo em dúvida o liberalismo político e a democracia. Se cabe exigir uma ação em favor da mudança social, ele deve empreendê-la organizando a economia e em particular o crédito. O governo ideal seria um governo tecnocrático que tivesse a capacidade de planejar os assuntos econômicos [...] Em Saint-Simon e sua escola o progresso é representado como uma linha contínua que deverá levar a uma nova sociedade da fartura onde reinará a harmonia universal [...] A utopia social saint-simoniana vai ao encontro do próprio desenvolvimento do capitalismo e do bemestar que ele poderá promover em toda a sociedade. (FALBEL in GUINSBURG, 2005, p. 37-38)

Diante disso, convém lembrar que Monteiro Lobato dialogou recorrentemente com princípios tanto positivistas quanto progressistas, defendendo, inclusive, a devida adaptação desses preceitos para a realidade brasileira. No entanto, a forma irônica com a qual a idealização automobilística de Ayrton Lobo e suas funestas conseqüências são figuradas em $O$ presidente negro parece indicar certa consternação pelo modelo que se instaurava pragmaticamente nas grandes cidades. Depois de seu acidente, o protagonista reconhece diante do Professor Benson as ilusões que o envolveram e pede um emprego na propriedade do cientista para que não tenha que enfrentar a vergonha de seu declínio social diante de seus conterrâneos, já que o automóvel fora completamente destruído.

Animado pela bonomia do velho, abri meu coração. Contei-lhe a mediocridade da minha vida, os meus esforços para juntar o pecúlio empatado no automóvel, a transformação que as quatro rodas me operaram na mentalidade e o horror com que via agora o forçado regresso ao pedestrianismo. (LOBATO, 1979, p. 10)

Ao problematizar o idealismo progressista no romance, Lobato fornece um contraponto ao ambiente de desenvolvimento técnico da urbe que também apresentava seus traços utópicos: o meio rural. O evidente deslumbramento de Ayrton Lobo pela paisagem e pela serenidade campestre é um aspecto importante tanto em termos narratológicos quanto temáticos. Em primeiro lugar, é o fascínio do protagonista pelo cenário bucólico que causa o seu acidente e possibilita a sua aproximação do cientista e de sua filha.

A região que eu atravessava era de maravilhosa beleza. Serras azues ao longe, quais muralhas de safira a sopesarem um céu de cobalto. Dia de limpidez absoluta. Paisagem das que vibram de nitidez. Desafeito aos formosos quadros da natureza, distrai-me com a novidade do espetáculo e... cataprus! (LOBATO, 1979, p. 09) 
Além disso, diante da serenidade da paisagem interiorana, quase intocada pelo homem, Ayrton reflete sobre o seu papel na frenética realidade urbana e a pequenez dos egos inflados por títulos, carreiras e capital. Em meio à natureza, a personagem encontra a possibilidade de perceber e afirmar o seu valor como indivíduo, uma significação que ultrapassaria sua posição profissional e econômica. Se, por um lado, a visão idealística da natureza e do retorno do homem ao seu meio parece se remeter diretamente à sensibilidade romântica de autores como Emerson e Thoreau; por outro lado, é preciso também reconhecer a vívida presença desse tema na literatura de realistas da estirpe de Eça de Queirós, especialmente em obras como $A$ ilustre casa de Ramires (1900) e A cidade e as serras (1901).

A impressão geral que tive diante da natureza liberta da presença e ação do homem, coisa que via pela primeira vez, foi da minha absoluta niilidade - da niilidade absoluta dos meus patrões, aquele momento a se esbofarem no escritório e a maldizerem do empregado desaparecido sem licença. - Para eles era eu o empregado - e também vinte dias antes eu me considerava apenas um empregado, isto é, humilde peça da maquina de ganhar dinheiro que os senhores Sá, Pato \& Cia. houveram por bem montar dentro de uma certa aglomeração humana. Mas ali não me via empregado de ninguém; era um ser igual ás ervas que esverdeciam as colinas, ás arvores que frondejavam nas grotas e ás aves que piavam nas moitas. Sentia-me deliciosamente integrado na natureza. (LOBATO, 1979, p. 16-17)

No entanto, o ambiente natural no romance é também o espaço no qual a personagem encontra um exemplo categórico das surpreendentes possibilidades da ciência. Nesse sentido, o contato de Ayrton com o meio rural não se caracteriza, necessariamente, como um retorno a uma matriz orgânica de existência, como defendiam alguns românticos. Comoa afirma o Professor Benson, o afastamento da cidade e de suas exigências cotidianas oferece uma oportunidade para o protagonista se dedique tanto a uma visão estética mais profunda do mundo quanto a um pensamento racional mais elaborado.

- O senhor Ayrton, interveio o professor, vai ficar aqui conosco. Tem muito que ouvir e aprender. Vou revelar-lhe os segredos da natureza, e tu, Jane, Ihe revelarás a poesia. Estes homens da cidade têm a visão muito restrita; o mundo para eles se resume na rua, nas casas marginais e no torvelinho humano. (LOBATO, 1979, p. 23)

Ainda que a crítica ao ritmo de vida no meio urbano seja aparente, o protagonista regressa para o Rio de Janeiro e retoma suas funções na Sá, Pato e Cia após o falecimento do Professor Benson. As necessidades práticas da vida moderna impõem sua urgência diante de uma sensibilidade recém-despertada. 
Esse complexo movimento retórico entre as idealizações da metrópole progressista e do campo emancipatório é significativo para refletir sobre os temas discutidos na obra e hipostasiados como utopias. Ao contrário do que sustentam certos analistas do romance de Lobato, a defesa autocrática de certas perspectivas por parte do autor não nos parece tão óbvia. Além da já mencionada ironia constantemente presente na sua dicção literária, os contrapontos apresentados para as utopias figuradas, a nosso ver, afastam 0 presidente negro de uma categorização definitiva como romance de tese. 0 autor transcende a esfera de seus posicionamentos individuais e discute em sua narrativa os prós e os contras de diferentes teorias sociais, o que denota a complexidade das questões dessa ordem. Indubitavelmente, a mais polêmica dentre elas é a eugenia como prática de aperfeiçoamento coletivo.

\section{A UTOPIA EUGÊNICA}

Em síntese, o conceito de eugenia pode ser definido como uma teoria que objetiva o aperfeiçoamento das comunidades humanas, tendo como base determinadas hipóteses de aprimoramento genético da espécie. O termo foi concebido no século XX pelo antropólogo Francis Galton, cuja teoria exortou a tomada de controle da humanidade sobre a sua própria evolução. Ainda que comumente associados a questões étnico-raciais, os princípios eugênicos teoricamente poderiam ser aplicados a uma ampla gama de variantes biológicas e comportamentais do ser humano. Não obstante, o entendimento compartilhado por muitos de que haveria uma hierarquia genética entre as raças, favoreceu não apenas uma violenta discriminação de grupos considerados inferiores, mas também uma ênfase no potencial transformador das práticas eugênicas.

Obviamente, não é necessário nos delongarmos sobre exemplos históricos desta forma de ufanismo seletivo em diferentes espaços e momentos do século XX. Das leis segregacionistas estadunidenses ao nazismo hitlerista a instrumentalização da eugenia como prática social é claramente apreensível.

$\mathrm{Na}$ utopia futurista figurada em $\mathrm{O}$ presidente negro, a evolução dos processos eugênicos foi extremamente bem sucedida nos Estados Unidos, o que culminou na sociedade do ano de 2028, retratada como eficiente e produtiva por Miss Jane. O evidente entusiasmo da senhorita Benson e os constantes comentários, ao mesmo tempo perplexos e ufanistas, do protagonista sugerem um tom satírico para a descrição, o que evidencia uma relativização dos preconceitos ao invés da sua defesa irrestrita. Contudo, manteremos por ora nossa atenção sobre a caracterização da utopia eugênica em solo estadunidense.

Já no início de sua apresentação, Miss Jane estabelece uma diferenciação entre os impulsos de transformação de americanos e latinos. Segundo ela, há um pragmatismo inerente aos projetos sociopolíticos nos Estados Unidos enquanto nos países de ascendência latina, incluindo as nações europeias, o desejo de mudança sempre desvanece nas brumas da 
utopia. Comportamentos tão contrários seriam resultantes, de acordo com a personagem, de predisposições genéticas transmitidas por meio do sangue ao longo dos séculos.

O idealismo dos americanos não é o idealismo latino que recebemos com o sangue. Possuem-no de forma especifica, própria, e de implantação impossível em povos não dotados do mesmo caráter racial. Possuem o idealismo orgânico. Nós temos o utópico. Veja a França. Estude a Convenção Francesa. Sessão permanente de utopismo furioso - e a resultar em que calamidades! Por quê? Porque irrealizável, contrario a natureza humana. Veja agora a América. Em todos os grandes momentos da sua historia, sempre vencedor 0 idealismo orgânico, o idealismo pragmático, a programação das possibilidades que se ajeitam dentro da natureza humana (LOBATO, 1979, p. 47)

Como podemos notar, o termo utopia é utilizado nesta passagem com a acepção de um projeto irrealizável e, portanto, antinatural em oposição a uma noção de idealismo funcional supostamente bem sucedido em termos práticos. Entretanto, no romance lobateano o pragmatismo estadunidense também se converte em uma projeção utópica futurista vislumbrada por meio do equipamento inventado pelo Professor Benson. Com isso, duas formas de idealização social são contrapostas por meio da noção de viabilidade prática.

Para Miss Jane, questões biológicas e raciais são responsáveis pela separação entre o que ela denomina idealismo e utopia. À guisa de exemplificação, a personagem cita o industrial Henry Ford, visto como a encarnação "natural" do bom senso estadunidense e do espírito progressista. A personagem afirma, inclusive, que Ford representaria a gênese de uma forma de idealismo orgânico que teria influenciado diretamente o futuro dos Estados Unidos, tendo como corolário a sociedade vislumbrada pelo porviroscópio.

Por mais audacioso que nos pareça o pensamento de Henry Ford, que é ele senão o reflexo do mais elementar bom senso? [...] No entanto, tamanha é a crosta que nos recobre o bom senso natural que Ford nos parece um messias da Ideia Nova. [...] Ninguém melhor do que eu poderá dizer isto de Henry Ford, porquanto devassei o futuro e por toda parte vi reflexos do seu pensamento. $\dot{E}$ pois o melhor tipo atual do idealista orgânico. Sonha, mas sonha a realidade de amanhã (LOBATO, 1979, p. 47-48).

Novamente, percebemos na passagem acima a valorização de um pensamento essencialmente racional e pragmático como força motriz para a articulação de um novo modelo de sociedade, baseada na ciência e na tecnologia.

Não obstante, Miss Jane não confere primazia aos recursos tecnológicos na formação da utopia eugênica. Em sua descrição, a personagem aponta, primeiramente, para uma matriz genética superior que, desde o período da colonização, singulariza a população estadunidense. 
Segundo ela, o povo americano foi formado a partir da emigração dos melhores espécimes humanos encontrados no continente europeu.

E o mundo americano não podia deixar de ser assim, senhor Ayrton, continuou ela. Note apenas: que é a América, senão a feliz zona que desde o inicio atraiu os elementos mais eugênicos das melhores raças europeias? Onde a força vital da raça branca, se não lá? Já a origem do americano entusiasma. Os primeiros colonos, quais foram eles? A gente do Mayflower, quem era ela? Homens de tal têmpera, caracteres tão shakespearianos, que entre abjurar das convicções e emigrar para o deserto, para a terra vazia e selvagem onde tudo era inospitalidade e dureza, não vacilaram um segundo. Emigrar ainda hoje vale por alto expoente de audácia, de elevação do tônus vital. Deixar sua terra, seu lar, seus amigos, sua língua, cortar as raízes todas que desde a infância nos prendem ao solo pátrio, haverá maior heroísmo? Quem o faz é um forte, e só com esse fato já revela um belo índice de energia. Mas emigrar para o deserto, deixar a pátria pelo desconhecido, isto é formidável! (LOBATO, 1979, p. 48)

$\mathrm{Na}$ ficção de Lobato, essa qualidade genética inata foi complementada pela seleção progressivamente mais rigorosa dos emigrantes que adentravam o território estadunidense. Segundo Miss Jane, o gênero humano naquela nação se inscreveu, consequentemente, em um processo evolutivo irrefreável, uma vez que os indivíduos considerados geneticamente superiores eram aceitos como cidadãos e o restante reconduzido para seus locais de origem. Com isso, o desenvolvimento da nação americana se consolidou como um fenômeno exemplar das teorias eugênicas e formou uma barreira protetora contra a expansão de raças orientais consideradas inferiores. Em uma determinada passagem, a personagem afirma, inclusive, que o destino dos países europeus seria o da submissão genética a raças asiáticas, uma vez que no velho continente os governos optaram por uma política que priorizava os direitos de classe e não a qualidade biológica. "Cada vez mais vai sendo a Europa drenada de seus melhores elementos - as suas mariposas, e a Europa acabará amarelada pela pigmentação mongólica. Isso vi eu já bem denunciado nos cortes feitos no século 25" (LOBATO, 1979, 48-49).

Entretanto, a violenta condução de escravos africanos para a América é reconhecida pela própria senhorita Benson como uma das principais falhas do fenômeno estadunidense. Diante dessa questão, o protagonista enaltece a miscigenação brasileira como uma solução pragmática e ainda mais racional do que a separação de raças nos Estados Unidos.

Também aqui arrostamos com igual problema, mas a tempo acudimos com a solução pratica - e por isso penso que ainda somos mais pragmáticos do que os americanos. A nossa solução foi admirável. Dentro de cem ou duzentos anos terá desaparecido por completo o nosso negro em virtude de 
cruzamentos sucessivos com o branco. Não acha que fomos felicíssimos na nossa solução? (LOBATO, 1979, p. 49)

Em contrapartida, Miss Jane reafirma a superioridade da lógica americana ao encontrar na divisão das raças uma saída para o problema. Segundo ela, a miscigenação é um processo que enfraquece os grupos raciais envolvidos e impõe uma inclusão que jamais será estável.

A nossa solução foi medíocre. Estragou as duas raças, fundindoas. O negro perdeu as suas admiráveis qualidades físicas de selvagem e o branco sofreu a inevitável piora de caráter, consequente a todos os cruzamentos entre raças dispares. Caráter racial é uma cristalização que às lentas se vai operando através dos séculos. O cruzamento perturba essa cristalização, liquefá-la, torna-a instável. A nossa solução deu mau resultado. (LOBATO, 1979, p. 49).

Nos Estados Unidos de O presidente negro, a resolução da questão racial ocorreu paulatinamente e envolveu ações e processos específicos. Em primeiro lugar, as recorrentes ondas imigratórias de europeus garantiram uma superioridade numérica dos brancos sobre os negros na proporção de seis para um, o que garantiu a preservação da qualidade genética da população considerada pura, que, por sua vez, deveria evitar qualquer tipo de contaminação de sua herança genética. O combate à mistura de raças com base em ideais eugênicos é um pressuposto de projeções utópicas como, por exemplo, $A$ república de Platão, na qual encontramos o mito das raças metálicas. Como salienta Teixeira Coelho,

Até a mistura entre os metais 'nobres' e 'baixos' deve ser evitada, porque da mescla surgirão a 'variação' e a 'absurda irregularidade', coisas que, segundo o projeto, não devem aparecer numa sociedade que se procura aperfeiçoar também através do controle da concepção, e não apenas da natalidade. (COELHO, 1985, p. 37)

Porém, os dirigentes estadunidenses ainda buscam no continente europeu o fortalecimento da matriz biológica da nação. Quando o fluxo de entrada de estrangeiros arrefeceu, o governo assumiu a prática de "importar" tipos humanos eugenicamente desejáveis para que o equilíbrio se mantivesse.

Em vez de entrada franca a quem quisesse vir localizar-se no país, organizou o governo americano em todas as nações do velho mundo um serviço de importação de valores humanos, consistente em atrair para lá a fina flor eugênica das melhores raças europeias. Já aliviada do seu ouro em favor da América, viu-se a Europa também aliviada da sua elite. (LOBATO, 1979, p. 52) 
Quando o risco de superpovoamento do território foi percebido, as fronteiras americanas foram simplesmente fechadas. Porém, a própria eugenia se tornou um problema a ser contornado. A preocupação dos descendentes europeus em salvaguardar a distinção genética de seu povo fez com que a taxa de natalidade se reduzisse gradualmente, até o ponto de ser superada pela dos negros. "Os brancos entraram a primar em qualidade, enquanto os negros persistiam em avultar em quantidade" (LOBATO, 1979, p. 52).

Diante disso, foram criados órgãos reguladores do crescimento demográfico que, apoiados nos postulados de cientistas e intelectuais adeptos da eugenia, criaram leis para a procriação humana e métodos funcionais para a seleção dos indivíduos. Surgiu, assim, o Ministério da Seleção Artificial, que a princípio estendia suas normas apenas para a raça negra, mas sem grande rigidez, tendo em vista a posição minoritária que ocupava. Não obstante, essa instituição impôs preceitos de aperfeiçoamento da espécie bastante severos, os quais extrapolavam drasticamente os limites da questão racial. Dentre eles, a recuperação e efetivação da famigerada lei espartana, segundo a qual crianças com deficiência ou má formação deveriam ser sacrificadas no momento do nascimento.

Entre cortar no inicio o fio da vida a uma posta de carne sem
sombra de consciência e deixar que dela saia o ser consciente
que vai vegetar anos e anos na horrível categoria dos
"desgraçados", a crueldade está no segundo processo. A lei
espartana reduziu praticamente a zero o numero dos
desgraçados por defeito físico. (LOBATO, 1979, p. 53)

Como afirma a própria Miss Jane, restavam ainda os "desgraçados" por defeito mental. Ao se referir a essa categoria, a personagem não se refere unicamente às síndromes ou transtornos mentais, mas também a supostos desvios de caráter e comportamento. Para que esse grupo também fosse obliterado, promulgou-se uma lei denominada Código da raça que previa a esterilização de todos os indivíduos que nele se encaixassem. Com isso, o ideal de depuração eugênica se transformou em política pública e pavimentou o caminho para a utopia. Os resultados desse processo são apresentados entusiasticamente pela senhorita Benson:

Só depois da aplicação de tais leis é que foi possível realizar o grandioso programa de seleção que já havia empolgado todos os espíritos. Desapareceram os peludos — os surdos-mudos, os aleijados, os loucos, os morféticos, os histéricos, os criminosos natos, os fanáticos, os gramáticos, os misticos, os retóricos, os vigaristas, os corruptores de donzelas, as prostitutas, a legião inteira de malformados no físico e no moral, causadores de todas as perturbações da sociedade humana. (LOBATO, 1979, p. 53)

Como podemos notar, a utopia eugênica figurada na obra transforma a ordem e o progresso social em questões essencialmente biológicas. Os 
procedimentos adotados não objetivam apenas evitar características físicas vistas como deformidades, mas também erradicar personalidades e condutas indesejáveis. Nesse sentido, as noções de ética e moral, comumente tratadas como de ordem sociocultural e historicamente determinadas, são entendidas como inerentes aos sujeitos, o que, por sua vez, converte a eugenia em teoria sociológica. Se considerarmos que, segundo os termos de Aristóteles, a physis é a esfera dos impulsos naturais humanos que são depurados pelo regulador ético (ethos) antes de se manifestarem no universo das ações práticas (práxis), podemos afirmar que a eugenia prescreve a manipulação da physis para que, a partir de um modelo de ser humano particular, a práxis seja invariavelmente marcada pela ética.

Destaca-se, assim, um aspecto recorrente nas projeções utópicas desde a obra de Thomas More: a homogeneização dos indivíduos. Nesta tradição, apreende-se o postulado segundo o qual um modelo de cidadão subjaz a estruturação da sociedade utópica e para que o equilíbrio e a harmonia do meio serem mantidos, a diversidade humana deve ser reduzida ou controlada. Podemos citar como exemplos a obra A cidade do sol (1602) de Tommaso Campanella, na qual magistrados decidem, com base na aparência física, os casais autorizados a manterem relações sexuais. E o romance Admirável mundo novo (1932), em que a manipulação genética ocorre no desenvolvimento do feto in vitro. "Numa série de frascos, óvulos biologicamente superiores, fertilizados por esperma biologicamente superior, recebiam o melhor tratamento pré-natal possível" (HUXLEY, 2000, p. 33). Em síntese, a edificação de um modelo de sociedade incorre, recorrentemente, na caracterização de um modelo de ser humano.

Apesar dos esforços para a consolidação desse modelo nos Estados Unidos da ficção de Lobato, a densidade demográfica dos negros aumentara vertiginosamente no ano 2228, uma vez que o Ministério de Seleção Artificial não atuava de maneira tão rígida nessa classe. Com isso, as populações das duas raças se tornaram praticamente equivalentes após algumas décadas, criando um problema urgente a ser resolvido pelos administradores da utopia ainda em formação. Diante da complexidade da questão, duas possíveis respostas foram aventadas da parte de cada uma das raças envolvidas. A chamada "solução branca" consistia em expatriar em torno de cem milhões de negros para o vale do Amazonas no Brasil, região considerada propícia (pelos brancos, obviamente) para a constituição biológica desses indivíduos. Em contrapartida, a "solução negra" defendia a divisão do território estadunidense, o que criaria uma fronteira entre norte e sul, que não seria apenas política, mas essencialmente racial.

A disparidade entre as duas propostas exemplifica o caráter dual de todo projeto utópico, ou seja, o idílio de um determinado grupo social pode representar o pesadelo de outro. Desvela-se, desse modo, o impulso totalizante que permeia em grande medida o utopismo: imaginativamente, a sociedade modelar é sempre construída sobre as bases de uma teoria 
monística, que desconsidera as especificidades dos indivíduos ou das coletividades envolvidas. Para que essa situação conflitante possa ser pacificada, os utopistas frequentemente descrevem em suas criações códigos legais bastante rígidos a serem seguidos por todos os cidadãos. É importante salientar que essas regulamentações são comumente legitimadas nas obras por suas associações a perspectivas teórico-filosóficas consideradas racionais ou humanistas, que seriam supostamente aceitas alegremente por todos os sujeitos. No entanto, a imposição da vigência dessas leis e a prescrição de duras penalidades para seus transgressores sugere um tom autoritário que não foi ignorado pelos críticos da utopia no século XX.

\begin{abstract}
Daí o protesto - e as antiutopias - de Aldous Huxley, Orwell ou Zamiatin (na Rússia do início da década de 1920), que pintam um quadro horripilante de uma sociedade sem atritos em que as diferenças entre os seres humanos são, tanto quanto possível, eliminadas, ou pelo menos reduzidas, e o padrão multicolorido dos vários temperamentos, inclinações e ideais humanos - em suma, o próprio fluxo da vida - é brutalmente reduzido à uniformidade, aprisionado em uma camisa-de-força social e política que fere e estropia, terminando por esmagar os homens em nome de uma teoria monística, do sonho de uma ordem perfeita e estável (BERLIN, 1991, p. 48-49)
\end{abstract}

Não obstante, como ocorre em algumas figurações da literatura utópica, a sociedade eugênica em $O$ presidente negro é apresentada ainda em processo de concretização. Esse recorte pode ser explicado especialmente por questões narrativas. Tradicionalmente, as utopias literárias apresentam uma dicção que se pauta na descrição dos aspectos que compõem o espaço ficcional. Consequentemente, a noção de conflito como elemento narratológico é muito reduzido ou quase nulo. Nessas obras, a caracterização de um estrangeiro ou de um viajante como protagonista é um recurso comum para viabilizar de forma coerente a exposição detalhada do núcleo utópico. Monteiro Lobato, todavia, prefere concentrar sua narrativa nos conflitos que redundaram na utopia eugênica americana, cujo formato definitivo é, inclusive, omitido por causa da limitação do porviroscópio. Em síntese, Lobato escolhe uma aproximação do tema oposta àquela de outros autores: ao invés de discorrer sobre o resultado final da aplicação de um projeto de sociedade, concentra-se nos eventos que possibilitam tal desfecho. Com essa abordagem, os conflitos se destacam sobremaneira no plano geral da narrativa.

A chamada "solução final" é apenas descrita nas últimas páginas do romance. Após a eleição presidencial de um líder negro, os dois partidos que representavam os brancos, anteriormente divididos por questão de gênero, novamente se unem contra o que é considerado um inimigo comum. É interessante perceber que, uma vez mais, as noções de utopia e antiutopia se revelam concentradas no mesmo evento e em seus desdobramentos, fazendo com que a distinção entre elas se estabeleça por meio da perspectiva dos 
envolvidos. A vitória de Jim Roy no pleito abre um horizonte de possibilidades para aqueles que até então sofreram com o preconceito e a estigmatização de seus genes, ou seja, uma utopia da raça negra parece se tornar realizável. "E a raça maior que o da mesquinha liberdade física, passou a sonhar o grande sonho branco da dominação..." (LOBATO, 1979, p. 85).

Ao mesmo tempo, o surpreendente resultado das eleições faz com que os brancos se deparem com a eventualidade de um regime de opressão semelhante ao que até então eles haviam imposto. Reafirmamos a reflexão anterior de que a utopia de um grupo se traduz como a antitutopia para o outro.

Nesse contexto, o choque entre as raças parece inevitavelmente fadado ao conflito belicoso.

- "E não trepidará o branco em esmagar a América se for condição para esmagar o negro?" rugiu.

Kerlog retrucou calmamente como se pela sua boca falasse o próprio deus do Orgulho:

- "Acima da América está o Sangue".

Jim baixou a cabeça. Viu aberto á sua frente o eterno abismo. (LOBATO, 1979, p. 87-88)

Contudo, a ciência apresenta um recurso pacífico, ainda que não menos terrível do que a guerra armada. Para descrever essa solução, cabe-nos, primeiramente, recuperar alguns elementos do enredo. No ano descrito por Miss Jane já havia ocorrido um amplo processo de "branqueamento" dos indivíduos negros que o desejassem. Porém, a tonalidade artificializada da pele resultante do processo e a impossibilidade de alterar o tipo de cabelo produziram um fenótipo intermediário que, na verdade, apenas aumentou a estigmatização dos negros. É importante notar que, uma vez esgotadas as possibilidades de manipulação genética da população por meio da imigração, o método científico já havia assumido a sua posição como instrumento de transformação da realidade social, ainda que, nesse caso, malograda.

No momento da eleição de Jim Roy, praticamente o processo de branqueamento havia atingido a totalidade da população negra. As recorrentes humilhações redundaram em uma forma de preconceito nutrida pelos próprios negros contra os resquícios físicos de sua raça. Essa internalização de uma suposta inferioridade atávica tem um caráter que não é apenas corporal, mas essencialmente identitário, uma vez que nos processos de alteridade se busca a integração em um modelo prescrito e autorizado pelo olhar do outro, que, em última análise, define a consciência do sujeito sobre si mesmo. Como afirma Frantz Fanton em sua obra Pele negra, máscaras brancas

O homem só é humano na medida em que ele quer se impor a um outro homem, a fim de ser reconhecido. Enquanto ele não é efetivamente reconhecido pelo outro, é este outro que permanece o tema de sua ação. É deste outro, do reconhecimento por este outro que dependem seu valor e sua 
realidade humana. É neste outro que se condensa o sentido de sua vida. (FANTON, 2008, p. 180)

Esse impulso de inclusão no modelo racial imposto é essencial para o triunfo do plano de reação desenvolvido pelo candidato derrotado Kerlog. Após uma reunião da chamada Convenção Branca, decide-se pela extinção da raça negra nos Estados Unidos, ainda que a forma prática de levar a cabo tão radical procedimento não é definida. A solução é encontrada na ideia do experiente inventor John Dudley, que percebe na estigmatização dos negros de suas próprias características físicas a oportunidade de uma reposta definitiva para a crise. Dudley descobre um tipo de irradiação, aparentemente inofensiva, que torna lisos os cabelos naturalmente crespos.

Os raios Omega, de sua descoberta, tinham a propriedade miraculosa de modificar o cabelo africano. Com três aplicações apenas o mais rebelde pixaim tornava-se não só liso, como ainda fino e sedoso como o cabelo do mais apurado tipo de branco. Os raios Omega influíam no folículo e destruíam nele a tendência de dar forma elíptica ao filamento capilar. Vencido este pendor para a forma elíptica, cessava o encarapinhamento, que não passa de mera consequência mecânica. (LOBATO, 1979, p. 101)

A descoberta científica é amplamente aceita e buscada pelos negros, culminando na submissão ao processo de todos os membros do grupo. Contudo, a irradiação esconde um efeito colateral: a total e irreversível esterilidade de todos os pacientes. Com isso, os conflitos encontram termo na inevitável extinção de uma delas, fazendo com que a utopia branca se consolide, tendo como base a instrumentalização de ideias da ciência e do progresso. $E$ isso ocorre justamente quando o primeiro e último presidente negro chegara ao poder. "Não ha moral entre raças, como não ha moral entre povos. Ha vitória ou derrota. Tua raça morreu, Jim... [...] Com a frieza implacável do Sangue que nada vê acima de si, o branco pôs um ponto final no negro da América" (LOBATO, 1979, p. 112).

\section{CONSIDERAÇÕES FINAIS}

Há centenas de anos a humanidade busca um caminho para alcançar a utopia de uma sociedade modelar. Diferentes períodos apontaram para direções diversas, mas sempre desembocaram em vias de mão dupla, nas quais a multiplicidade de perspectivas, ideologias e singularidades formavam seu próprio contra-fluxo. Enquanto reflexo desestabilizador da realidade, a utopia social sempre teve a antiutopia como sua irmã gêmea.

Nacionalismo, progresso, ciência e tecnologia são exemplos de ideais que podem servir de instrumento tanto para a construção de um idílio quanto para a concretização de um pesadelo. Porém, a distinção entre essas facetas não é de caráter imanente a nenhum deles, mas restrita aos seus usos e seus efeitos. 
Ao abordarmos a literatura de Monteiro Lobato e, em especial, o seu único romance, demonstramos a valiosa e complexa participação de um de nossos mais reconhecidos escritores no caleidoscópio de visões, reflexões e críticas que marcaram a modernidade e, especificamente, as primeiras décadas do século XX. Percebemos de que forma o autor tangencia 0 utopismo não apenas na dimensão temática de suas obras, mas também na sua própria compreensão da arte literária como vetor de aprimoramento individual e social.

Não obstante, a retórica de Lobato em seus textos ficcionais ultrapassa em grande medida a esfera da defesa arraigada de teses. Para tanto, os contrastes e os contradiscursos - aparatos inalienáveis da literatura utópica servem como elementos de problematização da dimensão argumentativa da própria obra. Ao desnudar as facetas de um mesmo ideal, as obras de Lobato se afastam da preleção e incitam a reflexão.

Esse aspecto se mostra de forma admirável em $O$ presidente negro. Seja na compensação automobilística de Ayrton para a sua vida proletária ou na valorização do ambiente natural em oposição ao progresso dos centros urbanos, as idealizações são retiradas de suas posições aparentemente totalizantes e realocadas na matriz dialética da qual surgem.

Especificamente em relação ao tema da eugenia, o romance demonstra a tênue linha que separa o progresso do artificialismo, a ciência dos dogmas, a igualdade da homogeneidade, a autoafirmação da crueldade; enfim a utopia da antiutopia. E, finalmente, demonstra a forma pela qual os discursos sociais podem influenciar a própria percepção de nossa identidade, o que pode nos levar a buscar idealizações que não apenas não são nossas, mas que podem nos destruir.

Tendo completado recentemente noventa anos de sua primeira publicação, O presidente negro reafirma sua importância como romance que trata, dentre tantos outros temas, da noção de perspectiva. E seja qual for o século a ser vivido, o caminho a ser trilhado e a utopia a ser buscada, essa não é uma questão minimamente irrelevante.

\title{
MODERNITY, UTOPIA AND EUGENICS IN O PRESIDENTE NEGRO BY MONTEIRO LOBATO
}

\begin{abstract}
This article aims to discuss the different utopian figurations that may be apprehended in the only novel written by the Brazilian author Monteiro Lobato which is titled $O$ presidente negro and was published in 1926. After a brief presentation of the author's affiliation to some of the sociocultural debates that marked the beginning of the $20^{\text {th }}$ century, we intend to analyze the ways the
\end{abstract}


novel depicts the idealizations and the intolerance that permeated the period, aspects that demonstrate the complex and many times contradictory of modernity itself and utopianism as a critical attitude towards reality. Hence, we intend to emphasize the importance of the novel which, even after ninety years of its first publication, still questions in a relevant way the tenuous limits between the social dreams and nightmares.

Keywords: Modernity. Utopia. Eugenics. Lobato.

\section{REFERÊNCIAS}

BERLIN, Isaiah (1991). Limites da utopia: capítulos da história das idéias. São Paulo: Companhia das Letras.

CANDIDO, Antonio (2006). Literatura e sociedade. Rio de Janeiro: Ouro sobre azul.

CARVALHO, José Murilo de (1998). Pontos e bordados - escritos de história política. Belo Horizonte: Editora da UFMG.

COELHO, Teixeira (1985). O que é utopia? São Paulo: Brasiliense.

FANON, Frantz (2008). Pele negra, máscaras brancas. Trad. Renato da Silveira. Salvador: EDUFBA.

GUINSBURG, J. (org.) (2005). O romantismo. São Paulo: Perspectiva.

LOBATO, Monteiro (1959). Cartas escolhidas. São Paulo: Brasiliense. Vol. 1. . (1979) O presidente negro. São Paulo: Brasiliense.

. (1948) Prefácios e entrevistas. 2 ed. São Paulo: Brasiliense.

, (1994). Urupês. São Paulo: Brasiliense.

MATOS, Maria Izilda Santos de (2005). Âncora de emoções: corpos, subjetividades e sensibilidades. Bauru: EDUSC. 